\title{
ANALISIS PENGENDALIAN KUALITAS PRODUK KANTONG SEMEN PADA LINE IV PABRIK KANTONG PT SEMEN PADANG
}

\author{
Tri Ernita ${ }^{1}$ \\ ${ }^{1}$ Program Studi Teknik Industri Sekolah Tinggi Teknologi Industri (STTIND) Padang \\ email: triernita@yahoo.com
}

\begin{abstract}
PT Semen Padang is the oldest cement factory in Indonesia was established on March 18, 1910. Semen Padang is located in the Village District of Lubuk Kilangan Indarung Madya city of Padang, approximately $15 \mathrm{~km}$ from the center of Padang West Sumatra at an altitude of 350 above sea level. PT Semen Padang not only produce high quality cement, but also manufacture cement bags which will facilitate the distribution of cement. Bags of cement were produced under the Ministry of Transportation Distribution and PT Semen Padang or Bureau bag factory located at Km 2 By Pass street, Padang. Bureau bag factory produces $40 \mathrm{Kg}$ bag with size and the size of $50 \mathrm{~kg}$. Based on the results of the overall discussion on the control of product quality cement bags known that quality control is implemented is still not optimal. Paretto diagram of the processing, there are six causes of disability among other cement bags 1. Defects in the logo, 2. Glue the tube body portion is not flat, 3. Tube not cut / no separate, 4. Installation of the valve / valve is not appropriate, 5. Glue at the top and bottom of the bag uneven, and 6. Fold the top and bottom are not perfect. The most dominant defect occurs during the production process on line IV, namely, fold the top and bottom of the bag is not perfect for 26280 of the 77295 total defective products, defective bags or $34 \%$ of the total number of defective products and improper valve installation for 23575 of the 77295 total products disability, which has a defect rate of $30.5 \%$ of the existing number of defective products. Selanjutya based on analysis of a causal diagram is known that factors that cause many machining equipment occurred a defective product, so it needs to be evaluated again on machinery and equipment so as to reduce or eliminate defects that may occur. Then on analysis using $p$ control map for the entire product defects that occur in the production process shows that not all the data are within the control limits.
\end{abstract}

Keywords: Cause and Effect Diagram, Cement Bags, Control Charts P, Defective Products, Pareto Diagram, Quality Control.

\section{PENDAHULUAN}

PT Semen Padang (PTSP) merupakan pabrik semen tertua di Indonesia yang didirikan tanggal 18 Maret 1910. Pabrik baru dapat mulai beroperasi pada tahun 1913 dengan kapasitas 22.900 ton per tahun, bahkan pernah mencapai produksi sebesar 170.000 ton pada tahun 1939. PT Semen Padang tidak hanya memproduksi semen yang berkualitas saja, namun juga memproduksi kantong semen yang akan memudahkan pendistribusian semen. Kantong semen tersebut diproduksi di bawah Departemen Distribusi dan Transportasi PT Semen Padang atau Biro Pabrik Kantong yang berlokasi di Jalan By Pass Km 2 Bukit Putus, Padang. Biro pabrik kantong memiliki 4 area kerja yaitu line 1, line 2, line 3 dan line 4. Line 1 dan line 2 merupakan area untuk memproduksi kantong jenis sewing bag (kantong jahit) namun pada saat sekarang sudah berhenti beroperasi diakibatkan pengalihan penggunaan kantong semen ke pasted bag (kantong lem). Sedangkan line 3 dan line 4 memproduksi kantong jenis pasted bag. Line 3 beroperasi 1(satu) shift sehari (7 jam) dengan kecepatan $130 \mathrm{bag} /$ menit yang mana hanya memproduksi kantong untuk ukuran 40 $\mathrm{kg}$, sedangkan line 4 beroperasi 3 (tiga) shift sehari (24 jam) dengan kecepatan 180 bag/menit. Line 4 di setting untuk memproduksi kantong dengan ukuran $50 \mathrm{~kg}$.

Dalam memproduksi suatu produk, tentunya tidak akan terhindar dari kecacatan. Maka dari itu setiap perusahaan memiliki batas atau standar toleransi terhadap cacat 
yang terjadi untuk mengukur hasil kinerja perusahaan tersebut. Sama halnya dengan biro pabrik kantong yang juga memiliki standar toleransi terhadap cacat produk yang terjadi selama proses produksinya. Standar toleransi cacat yang ditetapkan pabrik kantong semen PTSP selama proses produksi yaitu sebesar $1,2 \%$ produk cacat yang tidak dapat diperbaiki dari jumlah produk yang diproduksi. Cacat produk yang terjadi selama proses produksi kantong semen seperti lipatan bagian atas dan bawah kantong tidak sempurna, pemasangan valve / katub tidak tepat, lem pada bagian atas dan bawah kantong tidak rata, cacat pada logo, tube (kantong setengah jadi) tidak terpotong/ tidak terpisah dan lem pada bagian badan tube tidak rata.

Dari hasil pengamatan awal maka diketahui masih terdapat banyak produk cacat yang seharusnya dapat diperbaiki namun pada akhirnya harus dibuang. Hal ini disebabkan karena besarnya jumlah produk cacat dan keterbatasan jumlah tenaga kerja yang dimiliki perusahaan, terbukti dari hasil pengamatan bahwa pada produksi kantong 40 $\mathrm{kg}$ jumlah persentase kantong cacat masih berada dalam batas toleransi yang telah ditetapkan oleh perusahaan. Sedangkan pada produksi kantong $50 \mathrm{~kg}$ persentase produk cacat banyak yang melebihi dari batas yang telah ditetapkan oleh perusahaan. Maka banyaknya produk cacat dalam proses produksi memberikan gambaran perlunya kajian mendalam mengenai pengendalian kualitas produk kantong semen di Biro Pabrik Kantong PT Semen Padang.

Dari uraian diatas, maka dapat dirumuskan masalah yang melatarbelakangi penelitian ini, yaitu :

1. Apa jenis cacat yang paling dominan pada proses pembuatan kantong semen?

2. Faktor - faktor apa saja yang menyebabkan kerusakan/kecacatan pada produk yang diproduksi Pabrik Kantong PT Semen Padang?

3. Apakah pelaksanaan pengendalian kualitas pada Pabrik Kantong PT Semen

Padang berada dalam batas kendali ?

Sesuai dengan latar belakang dan perumusan masalah yang didapatkan maka tujuan dari penelitian ini adalah untuk mengetahui penyebab produk cacat yang paling dominan dan mengidentifikasi faktor faktor penyebab kerusakan/ kecacatan pada produk serta mengetahui bagaimana pengendalian kualitas produk pada Biro Pabrik Kantong PT. Semen Padang menggunakan peta kendali.

\section{METODOLOGI PENELITIAN}

Jenis penelitian yang digunakan pada penelitian ini adalah penelitian deskriptif kualitatif yang bersifat studi kasus bertujuan untuk menguraikan tentang sifat-sifat dari suatu keadaan dengan menganalisa perbandingan tiap kriteria dan aternatif yang digunakan. Penelitian ini mengumpulkan informasi langsung tentang suatu gejala yang ada, yaitu gejala yang timbul pada saat penelitian dilakukan, (Narbuko, 2006). Data dan sumber data yang digunakan yakni data sekunder. Data sekunder adalah data yang diperoleh secara tidak langsung atau melalui perantara. Data sekunder yang dibutuhkan dalam penelitian ini adalah data jumlah kantong cacat dan data jenis cacat produksi. Tahapan - tahapan penelitian yang dilakukan adalah:

\subsection{Studi Literatur}

Mencakup studi tertentu untuk memperdalam dan memepertajam teori mengenai metode analisis pengendalian kualitas.

\subsection{Pengumpulan Data}

Pengumpulan data diperoleh dengan cara wawancara langsung dengan pihak yang berwenang, melakukan pengamatan langsung dan mengumpulkan data yang berasal dari dokumen pihak perusahaan.

Secara umum, data yang diperlukan untuk menganalisa dan memecahkan masalah dalam penelitian ini adalah data sekunder, yakni : (1.) data jumlah produk cacat; (2.) data kategori produk cacat.

\subsection{Pengolahan dan Analisis Data}

Pengolahan data dilakukan dengan menggunakan metode pengendalian kualitas statistik. Data yang digunakan adalah data variabel yaitu data yang berdasarkan karakteristik yang diukur secara sebenarnya.

Pada tahap ini, data yang diperoleh akan diolah dengan berpedoman pada landasan teori. Landasan teori yang akan digunakan dalam mengolah data, menganalisa, dan memecahkan masalah nantinya menggunakan 
3 (tiga) tools yaitu : (1.) menentukan produk cacat dominan; (2.) menentukan penyebab penyebab produk cacat; (3.) menentukan produk cacat terkendali atau tidak. Maka analisis data dapat dilakukan dengan menggunakan : (1.) diagram pareto ; (2.) diagram sebab - akibat ; (3.) peta kendali - p.

\section{HASIL DAN PEMBAHASAN}

Berdasarkan pengamatan yang telah dilakukan, maka dapat dikelompokan jenis cacat yang terdapat dalam proses produksi antara lain :

a. Cacat pada logo ;

b. Lem pada bagian badan tube tidak rata ;

c. Tube tidak terpotong/ tidak terpisah ;

d. Pemasangan valve/ katup tidak tepat ;

e. Lem pada bagian atas dan bawah kantong tidak rata ;

f. Lipatan bagian atas dan bawah tidak sempurna.

Pembagian jumlah kerusakan pada produksi bulan April 2015 berdasarkan jumlah jenis cacat yang tebanyak dapat dilihat pada tabel 4.2 :

Tabel 4.2 Jenis Cacat Kantong

\begin{tabular}{|c|l|c|}
\hline No & \multicolumn{1}{|c|}{ Jenis Cacat } & $\begin{array}{c}\text { Jumlah } \\
\text { kerusakan }\end{array}$ \\
\hline a & $\begin{array}{l}\text { Lipatan bagian atas dan bawah } \\
\text { kantong tidak sempurna }\end{array}$ & 26,280 \\
\hline b & $\begin{array}{l}\text { Pemasangan valve/ katup tidak } \\
\text { tepat }\end{array}$ & 23,575 \\
\hline C & $\begin{array}{l}\text { Lem pada bagian atas dan bawah } \\
\text { kantong tidak rata }\end{array}$ & 16,696 \\
\hline d & Cacat pada logo & 4,097 \\
\hline e & $\begin{array}{l}\text { Tube tidak terpotong/ tidak } \\
\text { terpisah }\end{array}$ & 3,772 \\
\hline f & $\begin{array}{l}\text { Lem pada bagian badan tube } \\
\text { tidak rata }\end{array}$ & 2,875 \\
\hline
\end{tabular}

Sumber: Biro Pabrik Kantong PT Semen Padang 2015

Sedangkan dari perhitungan yang dilakukan maka diperoleh hasil :

3.1 Hasil Penetapan Penyebab Produk Cacat yang Dominan berdasarkan Diagram Pareto

Untuk mengetahui produk cacat yang paling dominan maka peneliti menggunakan analisis dengan menggunakan Diagram Paretto. Untuk membuat diagram pareto terleih dahulu kita membuat tabel persentase jenis cacat kantong semen. Dengan menggunakan rumus berikut:

\% Kerusakan $=\frac{\text { Jumlah Kerusakan Jenis }}{\text { Jumlah Kerusakan Keseluruhan }} \times 100 \%$

Pada Gambar 4.1 dapat dilihat bahwa terdapat dua jenis cacat yang paling dominan terjadi selama proses produksi pada line IV, yaitu:

a. Lipatan bagian atas dan bawah kantong tidak sempurna sebesar 26.280 dari 77.295 total produk cacat, atau 34\% kantong cacat dari jumlah produk cacat;

b. Pemasangan valve tidak tepat sebesar 23.575 dari 77.295 total produk cacat, yang memiliki tingkat kecacatan sebesar 30,5\% dari jumlah produk cacat yang ada.

Pada Gambar 4.1 dapat dilihat bahwa terdapat dua jenis cacat yang paling dominan terjadi selama proses produksi pada line IV, yaitu:

a. Lipatan bagian atas dan bawah kantong tidak sempurna sebesar 26.280 dari 77.295 total produk cacat, atau $34 \%$ kantong cacat dari jumlah produk cacat;

b. Pemasangan valve tidak tepat sebesar 23.575 dari 77.295 total produk cacat, yang memiliki tingkat kecacatan sebesar $30,5 \%$ dari jumlah produk cacat yang ada. Jumlah komulatif dari kedua cacat dominan ini sebesar $64,5 \%$. Ini sudah mewakili sebagian besar dari penyebab kecacatan pada proses produksi kantong semen.

\subsection{Hasil Identifikasi Penyebab Cacat berdasarkan Diagram Sebab - Akibat}

Setelah mengetahui produk cacat yang dominan dengan menggunakan Paretto Diagram terlihat jelas bahwa jumlah cacat terbesar adalah lipatan bagian atas dan bawah kantong tidak sempurna dan pemasangan valve tidak tepat. Dengan demikian akan dilakukan analisis sebab-akibat untuk mengetahui faktor-faktor apa saja yang mempengaruhi proses pembuatan kantong semen. Hasil identifikasi penyebab cacat dapat dilihat pada gambar 4.2 
Hasil penetapan penyebab produk cacat dapat dilihat pada gambar 4.1 :

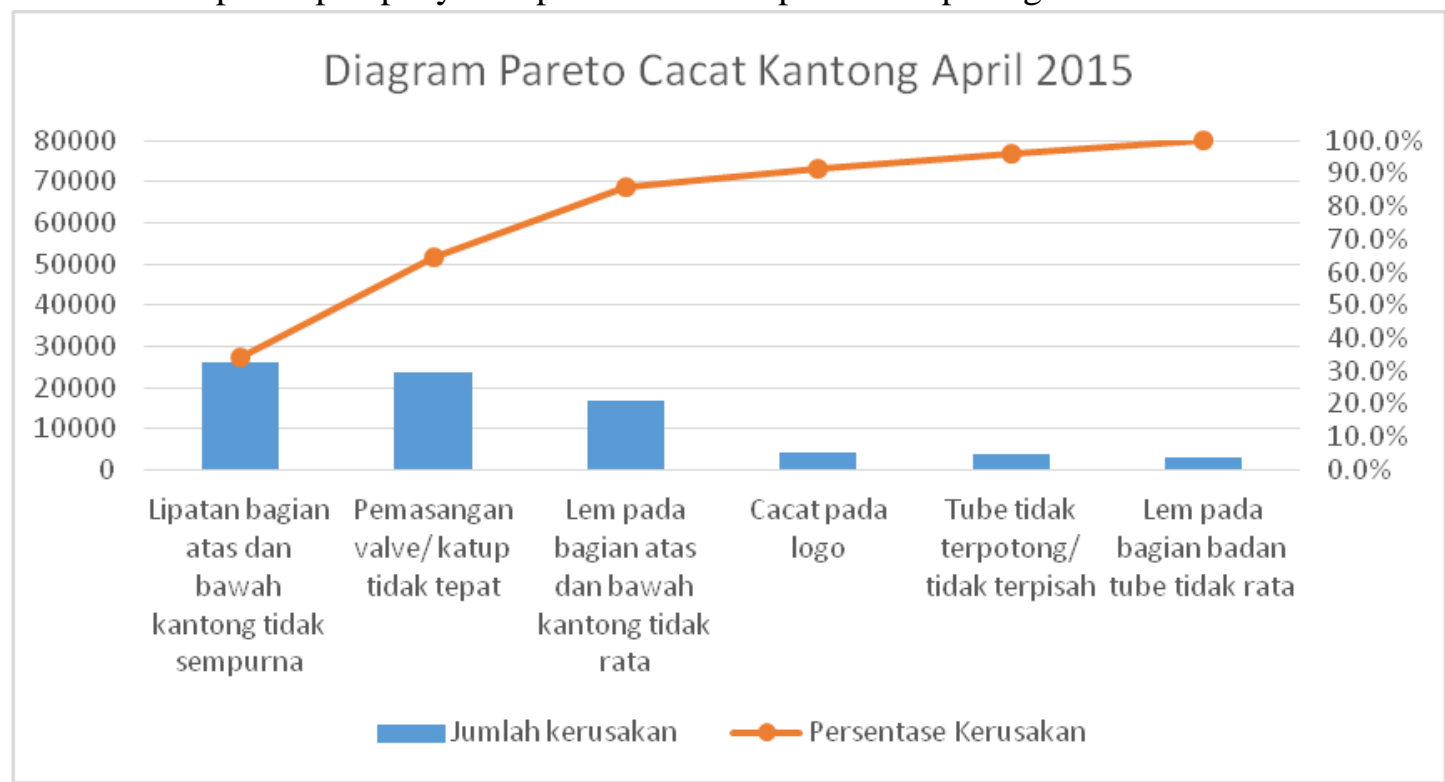

\section{Gambar 4.1 Hasil Penetapan Penyebab Produk Cacat Dominan}

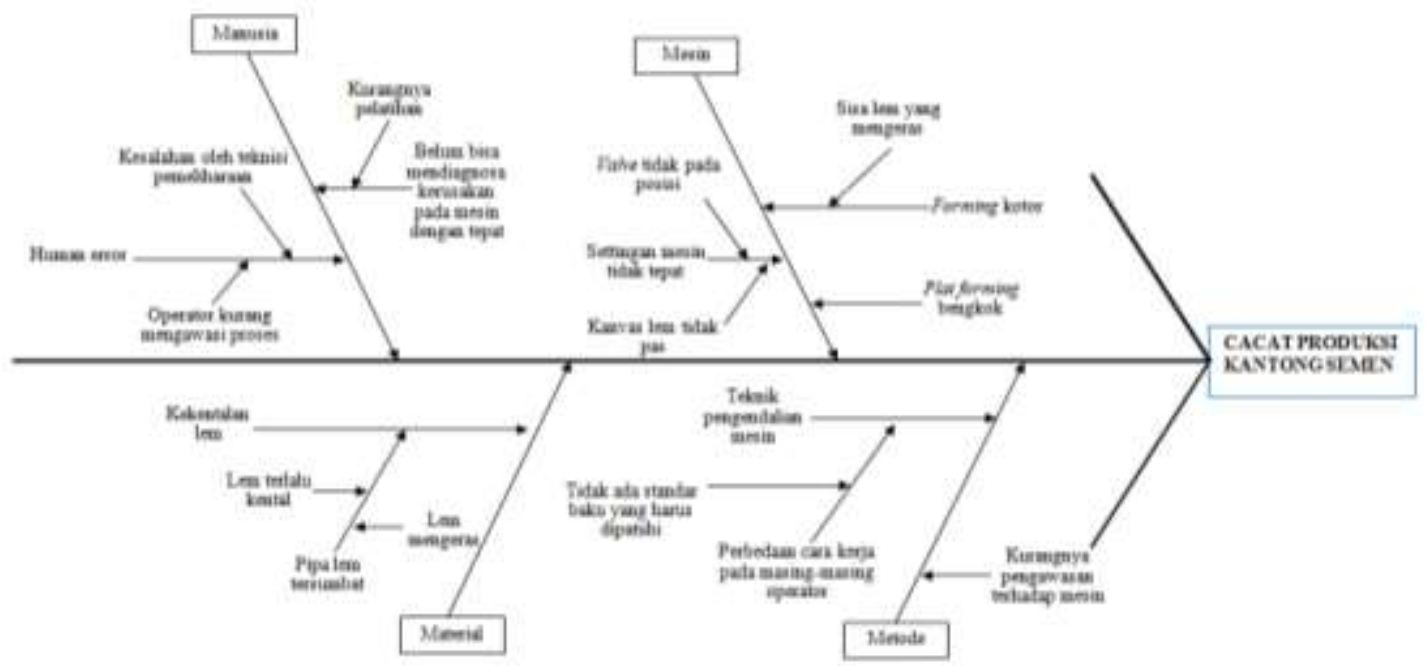

Gambar 4.2. Diagram Sebab Akibat Cacat Kantong

Gambar 4.2. diatas memperlihatkan data faktor penyebab terjadinya produk cacat dari mesin, manusia, material, dan metode.

1. Faktor mesin:

a. Valve tidak pada posisi yang benar, ini disebabkan karena settingan mesin yang tidak tepat.

b. Forming kotor, ini terjadi karena sisa lem yang melekat pada forming telah mengeras.

c. Plat forming bengkok.

d. Kanvas lem tidak pas

2. Faktor manusia:

a. Human error disebabkan karena operator kurang mengawasi proses dan kesalahan teknis oleh bagian pemeliharan.

b. Karyawan belum bisa mendiagnosa kerusakan pada mesin dengan tepat. Hal ini disebabkan karena kurangnya pelatihan yang diberikan kepada karyawan.

3. Faktor metode

a. Kurangnya pengawasan terhadap mesin

b. Teknik pengendalian mesin; perbedaan cara kerja masing-masing operator. Hal ini disebabkan karena tidak adanya standar baku yang harus dipatuhi. 
4. Faktor material

a. Kekentalan lem; pipa lem tersumbat, disebabkan karena lem terlalu kental atau lem yang telah mengeras.

\subsection{Hasil Pengukuran Kualitas Produk Sesuai Batas Kendali Berdasarkan Peta Kendali -P}

Peta kendali berfungsi untuk melihat apakah cacat yang terjadi setiap harinya homogen atau tidak. Hal ini bertujuan untuk mengendalikan kualitas produk. Dengan menggunakan aturan out of control dapat dilihat seberapa besar perbaikan yang harus dilakukan. Peta kendali yang akan digunakan untuk penelitian kali ini adalah peta kendali $\mathrm{P}$, dengan tahapan berikut :

a. Menghitung persentase kerusakan ;

b. Menghitung mean (CL) atau rata-rata jumlah produk cacat;

c. Menghitung batas kendali atas atau Upper Control Limit (UCL)

Untuk lebih jelasnya nilai perhitungan batas kendali pada produksi bulan April 2015 dapat dilihat pada tabel 4.3 dibawah ;

Tabel 4.3. Hasil Perhitungan Batas Kendali

\begin{tabular}{|c|c|c|c|c|c|c|c|c|}
\hline No. & Tanggal & Produksi & Cacat & Persentase Cacat & $p$ & $\mathrm{CL}$ & UCL & LCL \\
\hline 1 & 01 April 2015 & 264.000 & 3.466 & $1,31 \%$ & 0,0131 & 0,0142 & 0,0149 & 0,0135 \\
\hline 2 & 2 April 2015 & 164.000 & 2.590 & $1,58 \%$ & 0,0158 & 0,0142 & 0,0151 & 0,0133 \\
\hline 3 & 3 April 2015 & 128.000 & 1.879 & $1,47 \%$ & 0,0147 & 0,0142 & 0,0152 & 0,0132 \\
\hline 4 & 4 April 2015 & 172.000 & 2.466 & $1,43 \%$ & 0,0143 & 0,0142 & 0,0151 & 0,0133 \\
\hline 5 & 5 April 2015 & 216.000 & 3.008 & $1,39 \%$ & 0,0139 & 0,0142 & 0,0150 & 0,0134 \\
\hline 6 & 6 April 2015 & 212.000 & 3.180 & $1,50 \%$ & 0,0150 & 0,0142 & 0,0150 & 0,0134 \\
\hline 7 & 7 April 2015 & 216.000 & 3.444 & $1,59 \%$ & 0,0159 & 0,0142 & 0,0150 & 0,0134 \\
\hline 8 & 8 April 2015 & 228.000 & 2.964 & $1,30 \%$ & 0,0130 & 0,0142 & 0,0149 & 0,0135 \\
\hline 9 & 9 April 2015 & 204.000 & 2.876 & $1,41 \%$ & 0,0141 & 0,0142 & 0,0150 & 0,0134 \\
\hline 10 & 10 April 2015 & 240.000 & 3.600 & $1,50 \%$ & 0,0150 & 0,0142 & 0,0149 & 0,0135 \\
\hline 11 & 11 April 2015 & 120.000 & 1.566 & $1,30 \%$ & 0,0130 & 0,0142 & 0,0152 & 0,0132 \\
\hline 12 & 12 April 2015 & 180.000 & 2.700 & $1,50 \%$ & 0,0150 & 0,0142 & 0,0150 & 0,0134 \\
\hline 13 & 13 April 2015 & 192.000 & 2.630 & $1,37 \%$ & 0,0137 & 0,0142 & 0,0150 & 0,0134 \\
\hline 14 & 14 April 2015 & 220.000 & 3.320 & $1,51 \%$ & 0,0151 & 0,0142 & 0,0150 & 0,0134 \\
\hline 15 & 15 April 2015 & 224.000 & 3.360 & $1,50 \%$ & 0,0150 & 0,0142 & 0,0149 & 0,0134 \\
\hline 16 & 16 April 2015 & 164.000 & 2.460 & $1,50 \%$ & 0,0150 & 0,0142 & 0,0151 & 0,0133 \\
\hline 17 & 17 April 2015 & 152.000 & 2.232 & $1,47 \%$ & 0,0147 & 0,0142 & 0,0151 & 0,0133 \\
\hline 18 & 18 April 2015 & 248.000 & 3.320 & $1,34 \%$ & 0,0134 & 0,0142 & 0,0149 & 0,0135 \\
\hline 19 & 19 April 2015 & 180.000 & 2.178 & $1,21 \%$ & 0,0121 & 0,0142 & 0,0150 & 0,0134 \\
\hline 20 & 20 April 2015 & 204.000 & 3.066 & $1,50 \%$ & 0,0150 & 0,0142 & 0,0150 & 0,0134 \\
\hline 21 & 21 April 2015 & 224.000 & 2.913 & $1,30 \%$ & 0,0130 & 0,0142 & 0,0149 & 0,0134 \\
\hline 22 & 22 April 2015 & 160.000 & 2.360 & $1,48 \%$ & 0,0148 & 0,0142 & 0,0151 & 0,0133 \\
\hline 23 & 23 April 2015 & 160.000 & 2.400 & $1,50 \%$ & 0,0150 & 0,0142 & 0,0151 & 0,0133 \\
\hline 24 & 24 April 2015 & 228.000 & 3.192 & $1,40 \%$ & 0,0140 & 0,0142 & 0,0149 & 0,0135 \\
\hline 25 & 25 April 2015 & 160.000 & 1.789 & $1,12 \%$ & 0,0112 & 0,0142 & 0,0151 & 0,0133 \\
\hline 26 & 26 April 2015 & 96.000 & 1.344 & $1,40 \%$ & 0,0140 & 0,0142 & 0,0153 & 0,0131 \\
\hline 27 & 27 April 2015 & 180.000 & 2.841 & $1,58 \%$ & 0,0158 & 0,0142 & 0,0150 & 0,0134 \\
\hline 28 & 28 April 2015 & 116.000 & 1.624 & $1,40 \%$ & 0,0140 & 0,0142 & 0,0152 & 0,0132 \\
\hline 29 & 29 April 2015 & 120.000 & 1.531 & $1,28 \%$ & 0,0128 & 0,0142 & 0,0152 & 0,0132 \\
\hline 30 & 30 April 2015 & 72.000 & 998 & $1,39 \%$ & 0,0139 & 0,0142 & 0,0155 & 0,0129 \\
\hline & Total & 5.444 .000 & 77.295 & $1,42 \%$ & & & & \\
\hline
\end{tabular}

Peta kendali dapat dilihat pada gambar 4.3 dibawah ini :

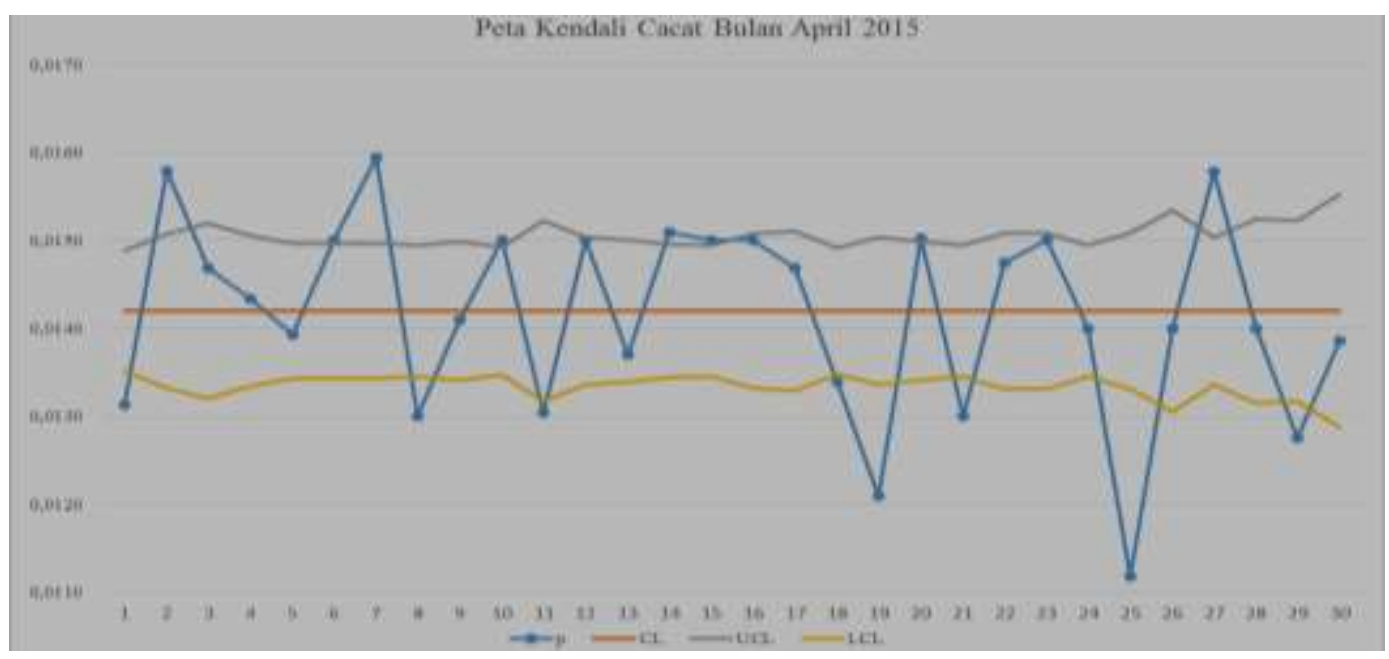

Gambar 4.3 Peta Kendali P 
Dari peta kendali $\mathrm{P}$ untuk produk cacat pada produksi kantong semen terlihat bahwa tidak semua data berada dalam batas kendali. Berdasarkan perhitungan peta kendali $\mathrm{p}$ maka diperoleh nilai Central line sebesar 0,0142. Terdapatnya data yang berada diluar batas kendali menandakan adanya penyebab yang tidak wajar yang mempengaruhi jalannya proses. Adanya cacat yang berada di luar batas kontrol, maka peta kendali $p$ perlu dilakukan revisi, yaitu dengan cara menghilangkan data yang melewati batas kendali. Data yang akan direvisi/ dihilangkan adalah data pada tanggal $1,2,7,8,10,11,14,15,18,19,21,25,27$, dan 29 april 2015. Berikut merupakan tabel revisi perhitungan batas kendali bulan April 2015 pada line IV pabrik kantong semen PTSP;

\section{KESIMPULAN}

1. Dari pengolahan diagram paretto, cacat yang dominan terjadi adalah lipatan bagian atas dan bawah kantong tidak sempurna sebesar 26.280 dari 77.295 total produk cacat, atau $34 \%$ kantong cacat dari jumlah produk cacat, dan pemasangan valve tidak tepat sebesar 23.575 dari 77.295 total produk cacat, yang memiliki tingkat kecacatan sebesar 30,5\% dari jumlah produk cacat yang ada. Total dari kedua cacat yang paling dominan ini adalah $64,50 \%$. Ini sudah mewakili sebagian besar dari penyebab kecacatan ;

2. Setelah dilakukan identifikasi diperoleh penyebab - penyebab cacat yang terjadi dan berdasarkan hasil tanya jawab yaitu terdapat pada faktor mesin antara lain valve tidak pada posisi yang benar, ini disebabkan karena settingan mesin yang tidak tepat, forming yang kotor karena sisa lem yang melekat pada forming telah mengeras dan plat forming bengkok yang mana ini merupakan faktor yang menyebabkan banyaknya produk cacat;

3. Pada analisis menggunakan peta kendali $p$ untuk seluruh produk cacat yang terjadi pada proses produksi terlihat bahwa terlihat bahwa tidak semua data berada dalam batas kendali.

\section{DAFTAR KEPUSTAKAAN}

Ariani, D. W. "Pengendalian Kualitas

Statistik”. ANDI. Yogyakarta. 2004.

Arman Hakim Nasution. "Manajemen

Industri”. ANDI. Yogyakarta. 2005.

Assauri, Sofjan. "Manajemen Produksi”.

Fakultas Ekonomi Universitas Indonesia. Jakarta. 2008.

Ervil, Riko, dkk. "Buku Panduan Penulisan Dan Ujian Skripsi”. STTIND Padang. Padang. 2012.

Heizer, Jay dan Barry Render. "Manajemen Operasi”. Salemba Empat. Jakarta. 2009.

Mitra Fajrina. "Pengendalian Kualitas Produk Briket Pada Industri Supreme Carbon”. Sekolah Tinggi Teknologi Industri (STTIND) Padang. 2015

Nasution, M. N. "Manajemen Mutu Terpadu”. Ghalia Indonesia. Bogor. 2001.

Nur, Indriantoro dan Bambang Supomo. "Metodologi Penelitian Bisnis". BPFE. Yogyakarta. 1999.

Prawirosentoso, Suryadi. "Filosofi Baru Tentang Manajemen Mutu Terpadu Abad 21 Kiat Membangun Bisnis Kompetitif”. Bumi Aksara. Jakarta. 2007.

Tjiptono, Fandy dan Anastasia Diana. "Total Quality Manajemen Edisi Revisi”. ANDI. Yogyakarta. 2001.

Winjosoebroto, Sritomo. "Pengantar Teknik Manajemen Indusri Edisi Pertama”. Guna Widya. Surabaya. 2003 